\title{
利用者意識構造の変化に基づくバスサービス 改善点の抽出とその改善方策に関する研究
}

\author{
佐々木 智英 1 高橋 清 2 ・芝崎 拓 3 -大井 元揮4 \\ 1学生会員 北見工業大学大学院 社会環境工学専攻（†090-8507 北海道北見市公園町165番地） \\ E-mail: m1352200063@std.kitami-it.ac.jp \\ 2正会員 北見工業大学教授 社会環境工学科（干090-8507 北海道北見市公園町165番地） \\ E-mail: kiyoshi@mail.kitami-it.ac.jp \\ ${ }^{3}$ 非会員＼cjkstart北海道開発技術センター（ $\bar{T} 001-0011$ 札幌市北区北11条西2丁目2番17号） \\ E-mail: shibazaki@decnet.or.jp \\ 4正会員＼cjkstart北海道開発技術センター（广001-0011 札幌市北区北11条西2丁目2番17号） \\ E-mail: ooi@decnet.or.jp
}

\begin{abstract}
本研究の対象地区である北海道北見市に位置する川東・若松地区では，バス交通の利便性向上や公共交 通空白地の解消を目的に平成24年12月から路線バスに代わるバス交通としてディマンドバスの実証運行が 実施され, 現在では, 本格運行が実施されている。 そこで本研究ではディマンドバス導入の事前・事後調 查から, 導入前後における利用者の意識構造をCSポートフォリオ分析を用いて視覚的に把握した。結果, 導入前後におけるバスサービスに対する満足度の向上，および利用者識構造の変化を明らかにするととも に, 今後の継続的運行に向けてバスサービスの改善すべき点を抽出し, 利用者からみたときの具体的な改 善策の検討を行った。
\end{abstract}

Key Words : public transport, demand bus, users consciousness structure, CS portfolio analysis, accessibility measure, bus diagram

\section{1. はじめに}

我が国におけるバス交通は，平成 14 年に道路運送法 の一部改正に伴い，それまでの需給調整規制が緩和され 参入退出の自由度が大幅に高まったこともあり，地方都 市などは利用者の減少と共に不採算バス路線の撤退が段 階的に進み，公共交通空白地域の拡大が目立つようにな った. 本研究の対象地域である北海道北見市のバス交通 においても，例外ではない，そのため北見市では，平成 23 年度に「北見市地域公共交通計画」が策定され, 市 内のバス交通について「路線の変更・新設」，「新たな 交通システムの導入」や「モビリティ・マネジメントの 推進」等の実施が計画された ${ }^{1}$. 特に，北見市川東地区， 若松地区では同計画において，バス交通の利便性向上や 公共交通空白・不便地域の解消を目指し, 従来の路線バ ス (若松線) に代わる新しいバス交通として，ディマン ドバスの導入検討が平成 24 年度から進められ, 平成 24 年 12 月には実証運行が実施された。 その後, 実証運行 を経たディマンドバスは，平成 25 年 10 月 1 日より本格
運行が開始されている2).

そこで本研究は，川東・若松地区住民を対象に，ディ マンドバス導入の事前及び事後アンケート調查を実施し, 利用実態及び利用者意識把握を行う。さらに得られた結 果から, CS (Customer Satisfaction)ポートフォリオ分析を用 いて，ディマンドバス導入前後における利用者意識の変 化を把握し，バスサービスの改善すべき点を抽出する. さらに，抽出した改善点について，今後の継続的な運行 に向けた取り組みとしての具体的な改善策を検討するこ とを目的とする.

\section{2. 既存研究と本研究の位置づけ}

バス交通に対する意識調査・分析に関する研究はこれ までに数多く報告されている. 坂本ら ${ }^{3}$ は埼玉県ときが わ町における路線バス再編前後でのバスサービス項目別 に把握した満足度の集計分析から, 路線バス再編の効果 と住民意識変化を明らかにしている．小林ら ${ }^{4}$ はバス到 
着時刻情報の取得実態と利用者意識を調査・集計により 把握し，バス利用者の情報取得に対しては消極的である ことを明らかにしている。こうした集計による意識把握 の他に, 意識を構造化して視覚的に把握する研究も多く みられる. 塚田ら 5)や斎藤・高野 9は自由記述意見を基 に，テキストマイニング手法を用いてバス交通に対する 意識を共起ネットワークにより構造化して把握している. 金井ら 7’ばス非利用者に対する今後のバス利用意向と バス路線存続意向に関する意識構造モデルを共分散構造 分析により明らかにしている。こうした調査・集計によ る再編前後での意識変化や 1 時点における意識構造を視 覚化し分析した研究は多く行われているが，実際に計画 策定の段階から実証運行, 本格運行といった一連のプロ セスの段階において住民の意識を構造的に把握し，改善 点を抽出している研究は少ない.

本研究の対象地区のような需要の少ない地域のバス運 行計画に関する研究では, 岸ら ${ }^{8)}$ が住民のニーズを踏ま えた生活交通手段の策定プロセスを提案している. 森山 ら ${ }^{9}$ は，中山間地域における公共交通の運行計画を支援 するためのツールとして，人口等に基づき 1 日のバス利 用者数や便数を決定するシステムを開発している。しか し，バス運行計画を考えるには，地区住民の活動実態を 時間単位で捉え，何時にバスを運行すればよいかという ダイヤを設定することが重要な視点の 1 つであると考え られる。

そこで，住民の活動機会に着目したバスダイヤの設定 方法を提案している研究として, 岸野ら ${ }^{10}$ は, 目的地に おける活動時刻とバスダイヤが与えられたとき，活動機 会の獲得水準を表すモデルを構築し，獲得水準を最大化 するバスダイヤの設定法を提案し，有用性を示している. しかし，本研究のようにバスダイヤに関する事前・事後 での評価や，具体的なバスダイヤの改善策を検討すると いったところまでには至っていない.

以上より，計画策定の段階から実証運行，本格運行と いった一連のプロセスの段階において住民意識を構造的 に把握し, 改善点を抽出している研究は少なく, その先 の具体的な改善策の検討まで行っている研究は見受けら れない.

\section{3. 対象地区のバス交通の概要}

\section{（1） 北見市川東地区 - 若松地区の概要}

北見市川東地区，若松地区は，北見駅から南東の方角 $2 \mathrm{~km}$ に位置しており，常呂川を一辺とした東西約 $7 \mathrm{~km}$, 南北約 $9 \mathrm{~km}$ の地区である. 人口は両地区合わせて 2,334 人，世帯数は 1,138 世帯であり，その内訳は，川東地区 が 2,192 人， 1,164 世帯であり，若松地区が 142 人， 78 世
帯(平成 26 年 6 月現在)である.また, 高齢化率は約 $30 \%$, 市内の中でも高齢者割合が高く, 人口密度が低 い典型的な郊外地区に位置付けられる。

\section{（2）旧路線バス (若松線)の概要}

本研究の対象地区を従来運行していた若松線は，1 日 9 便で運行していた路線バスである（図-1）。また，運 行ルートは図-1 に示すように, バス路線が両地区をう まくカバーできていない状況であった。このことは，利 用者のおよそ半数を占める高齢者等の交通弱者にとって， 大きな負担になっていた.

\section{(3) 導入されたディマンドバスの概要}

従来の路線バスが見直され，実証運行を経て，平成 25 年 10 月より本格運行が実施されているディマンドバ スは，「北見駅一北見老人ホーム」間を定時定路線とし て運行し，北見老人ホームから先を予約制のディマンド バスとして，定時定路線区間とディマンドバス区間を連 結した形態として運行された（図-2）.

これは，「北見駅一北見老人ホーム」間では住宅地が 多く立地しており，比較的密集した居住エリアであるが，

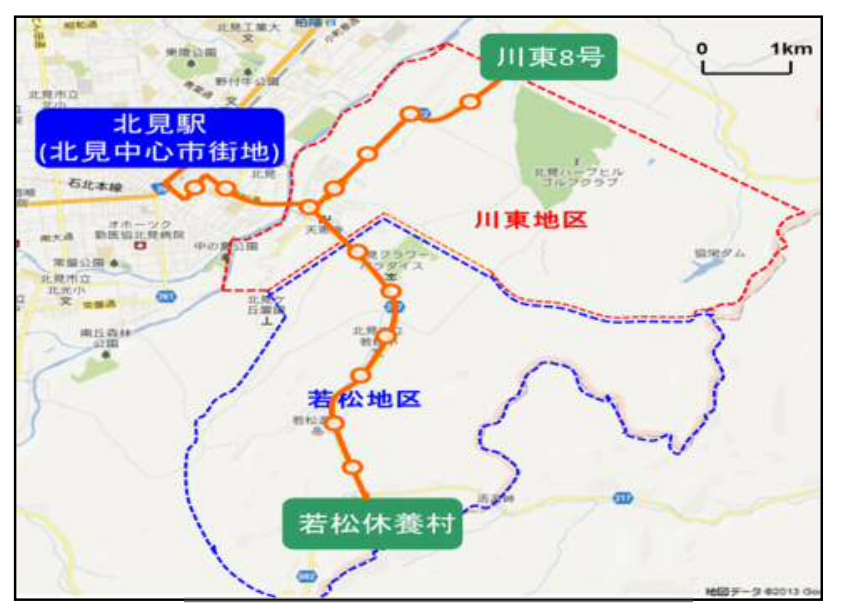

図-1 従来の若松線の路線図

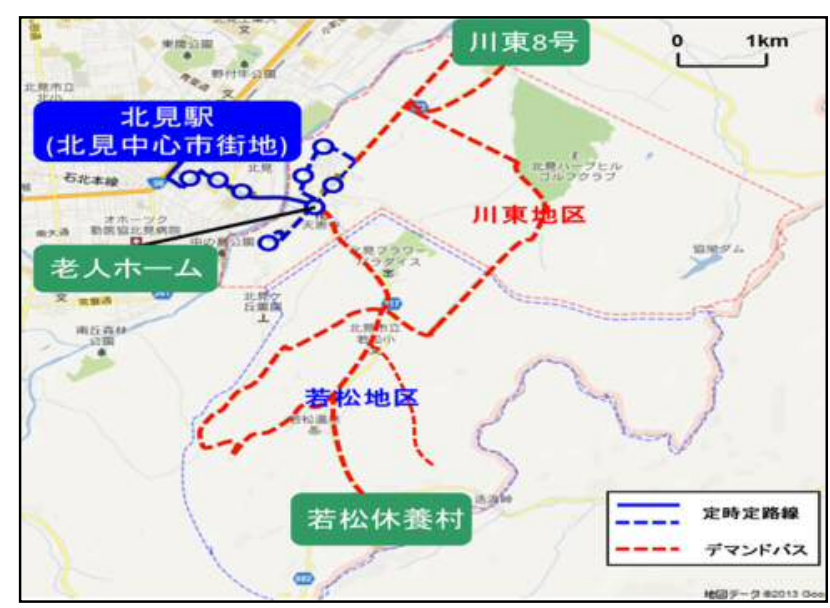

図-2 ディマンドバスの路線図 
北見老人ホームから先の郊外エリアでは住居が点在し， 農家等の低密度なエリアであるため, 従来のバス路線と 新たな路線を組み合わせた設計がなされたものである.

バスサービスの視点からみると, 運行ルートについて は，ディマンドバスを取り入れたことで両地区を広域的 にカバーすることが可能となった. ディマンド区間利用 については電話予約制となっており，1 便目の利用は前 日予約， 2 便目以降の利用では 2 時間前予約が原則とな っている. また, 車両自体は従来と比較し小型化され, 運転手を含む 14 人乗りのワゴン車で運行している.

その他，ディマンドバスの概要を表-1に示す.

\section{4. ディマンドバスの利用実態}

本格運行が継続しているディマンドバスの利用実態は 以下の通りである ${ }^{11)}$.

図-3 は，導入前の旧路線バスと導入後のディマンド バス実証運行期間及び，本格運行後の利用実態を 3 時点 で比較したものである.

図-3 より，旧路線バスとディマンドバス実証運行期 間で乗車人数が 7,486 人から 8,871 人と 1,385 人の利用者 増加が確認された. また, 平均乗車人数は 1 便当たり 2.36 人から 3.48 人と約 1.5 倍に増加している. このこと は, 従来の路線バスからディマンドバスへのシステム変 更に伴って「運行ルート」の新たな設定が潜在需要を取 り込むと同時に, 従来からの利用者の利用頻度が増加し たものと考えられる.

このように, ディマンドバスが導入されたことによっ て, 利用者の増加が確認されたため, 平成 25 年 10 月よ り本格運行が決定した。 また，旧路線バスのときと比較 して, 現在の本格運行では, 乗車人数が 12,580 人, 平均 乗車人数は 1 便当たり 3.99 人であり，年間乗車人数では 約 5,000 人の増加, 平均乗車人数は約 2 倍の増加が確認 されている.

\section{CS ポートフォリオ分析を用いた意識構造分析}

\section{(1) 事前·事後調査の概要}

本研究では関係機関と協力し, 平成 24 年に従来の路 線バスに対する調査, そして, 平成 25 年にディマンド バスに対する調査を実施した。 以降，平成 24 年の調査 を事前調査, 平成 25 年の調査を事後調查と記す. 以下, 調査概要を表-2 に示す.

(2) 導入前後における回答者年齢層割合の比較

事前・事後調査によって得られた回答者の年齢層割合
の比較を図-4 に示す. 図-4 より, 回答者の年齢層割合 は，導入前後で同様の傾向にあり，60 代〜80 代以上の 割合が高い.

表-1 ディマンドバスの概要

\begin{tabular}{|c|c|}
\hline \multirow{3}{*}{ 運行期間 } & 実証運行：平成24年12月10日 平成25年3月31日 \\
\hline & 平成25年4月1日 平成25年9月30日 \\
\hline & 平成25年10月1日 \\
\hline \multirow{2}{*}{ 車両 } & トヨタハイエースコミューター(ワゴン車）2台 \\
\hline & 四輪駆動，自動ドア，14人乗(運転手含む) \\
\hline \multirow{2}{*}{ 運賃 } & 定時定路線 大人 $210 円 / 小 人 110 円 ~ ※$ 平成26年4月より \\
\hline & ディマンド 大人 $410 円 /$ 小 $210 円 \quad$ 消費税分の 10 円増額 \\
\hline \multirow{3}{*}{ 料金制度 } & 身体障害者手帳·療育手帳保持者は半額 \\
\hline & 小人運賃は, 6歳 12歳(小学生) \\
\hline & 高齢者等無料バス乗車証利用可能 \\
\hline
\end{tabular}

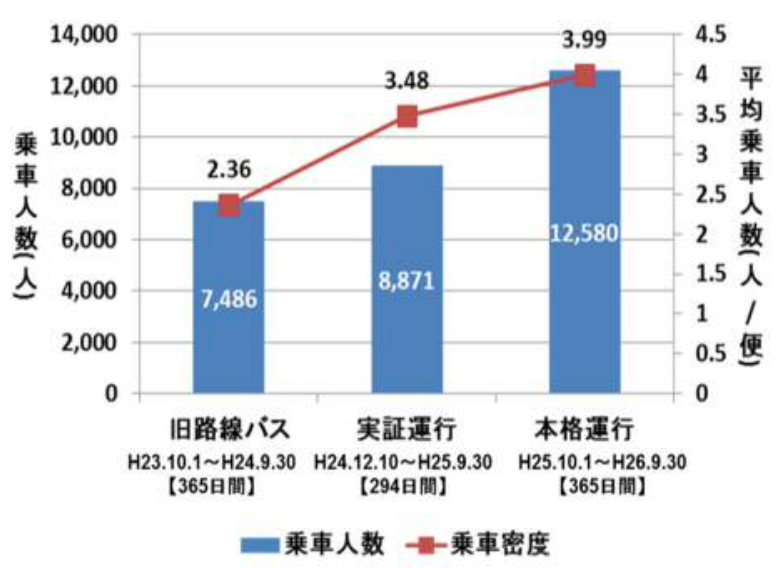

図-3３時点におけるバス利用実態の比較

表-2 事前・事後調査の概要

\begin{tabular}{|c|c|}
\hline 調查対象 & 15歳以上の北見市川東·若松地区住民 \\
\hline 配布票数 & 川東: 750票, 若松: 142票 計:892票 \\
\hline \multirow{2}{*}{ 調査回収期間 } & 事前調查：平成24年11月27日 平成24年12月14日 \\
\hline & 事後調査：平成25年11月29日～平成25年12月16日 \\
\hline 配布方法 & 川東: 直接配布, 直接回収 若松: 直接配布, 郵送回収 \\
\hline \multirow{2}{*}{ 回収票数 } & 事前調査：259票 回収率29.0\% \\
\hline & 事後調査：285票 回収率32.0\% \\
\hline 調査項目 & 個人属性, バス利用頻度, バスサービスに対する満足度 \\
\hline
\end{tabular}

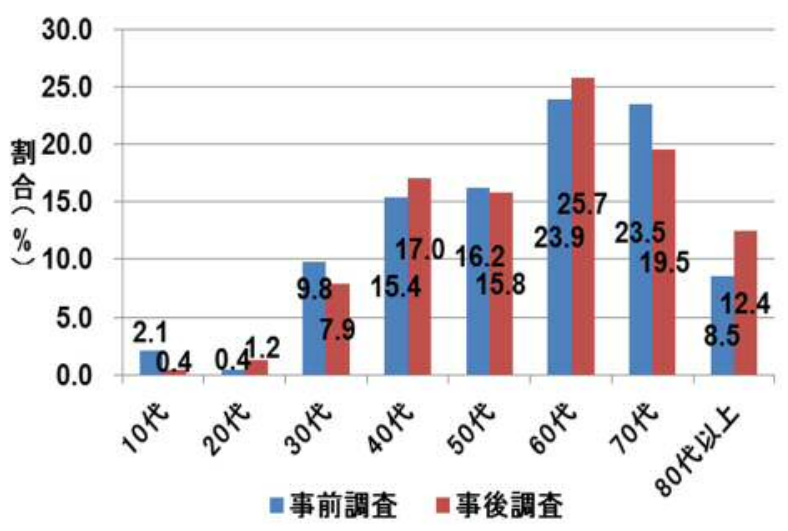

図-4 導入前後における回答者年齢層割合の比較 
(3) 導入前後におけるバス利用者満足度の変化

ディマンドバス導入前後における各バスサービス項目 に対するバス利用者満足度の変化を図-5に示寸，なお， 以下では満足度を質的データから量的データに変換する ため, 満足と回答した割合を算出し，これを「満足度」 として示している．図-5 から，ディマンドバスの導入 前後において，全 10 項目に対するバス利用者満足度が 向上していることが明らかとなった．特に「自宅からバ ス停までの距離」と「運行ルート」の満足度が大きく向

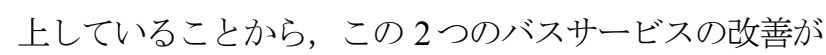
総合評価の向上に起因していると考えられる.

\section{(4) CSポートフォリオ分析手法の概要}

CS ポートフォリオ分析は, 顧客満足度 (CS: Customer Satisfaction)を用いて, 多数のサービスの中から優先的に 改善すべき項目を視覚的に把握することが可能な分析手 法である. その際, 満足度と重要度の 2 つの指標值を繸 軸と横軸とした CS ポートフオリオ図を作成する．この 図から，第 1 象限〜第 4 象限にプロットされた項目をそ れぞれ, 重要維持項目, 維持項目, 改善項目, 重要改善 項目と呼び，特に第4象限にプロットされる項目を優先 的に改善すべき項目であると解採される.

一般的に，「満足度評価項目が，総合満足度を向上さ せるためにどの程度影響しているのか」を定量化するた め, 総合評価と各満足度評価項目との相関係数または偏

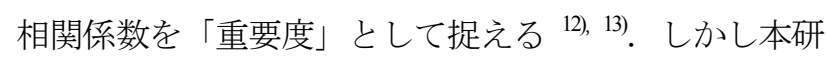
究では，重要度を住民があるサービスに対して改善を要 求している度合いと考え, 「要求度」と捉える. また, 満足度を 5 段階評価のカテゴリーとしているため, 質的 データ間の相関である独立係数を要求度として扱うこと とする。ささらに，満足度についても満足度回答した割 合を算出し，これを「満足度」として扱っている.

また, CS ポートフォリオ分析では軸交点のとり方と 縦軸・横軸の指標值によって各象限範囲が変わってしま い，分析結果に大きな違いが生じてしまう。そのため本 分析では, 満足度と要求度をそれぞれ偏差值化し, 軸の 統一化を図った，両軸を統一寸ることで自ずと軸交点の 座標は（50，50） と決まるため，各評価項目間の相対的 な位置関係を正確に図へと落とし込むことが可能になる。

\section{(5) 事前と事後におけるバス利用者の意識構造分析}

\section{a) 導入前における意識構造分析結果}

ディマンドバス導入前において, バス利用者の意識構 造を示した CS ポートフォリオ図を図-6に示す。なお， バス利用者については，年に 1 回以上バスを利用してい る人をバス利用者として集計を行った.

図-6より, 重要改善項目として「バスの遅れ」と 「乗車時間」の2つの項目が抽出され，乗車時間と比較
してバスの遅れの満足度が低く, 重要改善項目エリアに 位置している. このことから，バス利用者の意識として は，目的地までの乗車時間が長くなることよりも，バス の遅れにより, い到着するかわからない状況の中で待 たされることに不満を感じていると考えられる.

\section{b) 導入後における意識構造分析結果}

ディマンドバス導入後において, バス利用者の意識構 造を示したCS ポートフォリオ図を図-7に示寸.
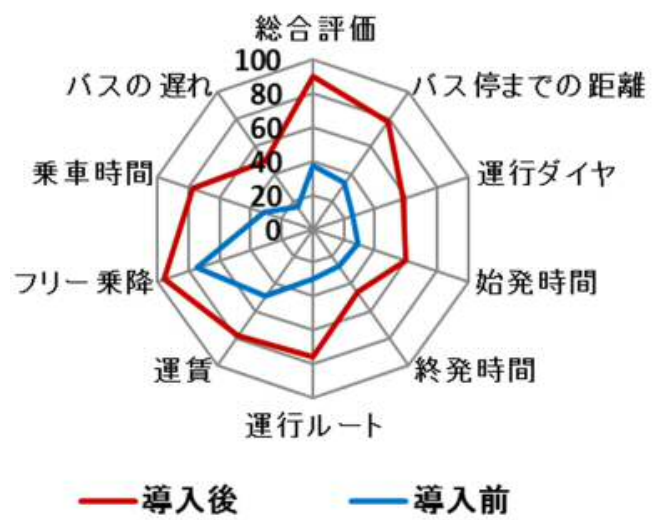

図-5 導入前後におけるバス利用者満足度の変化

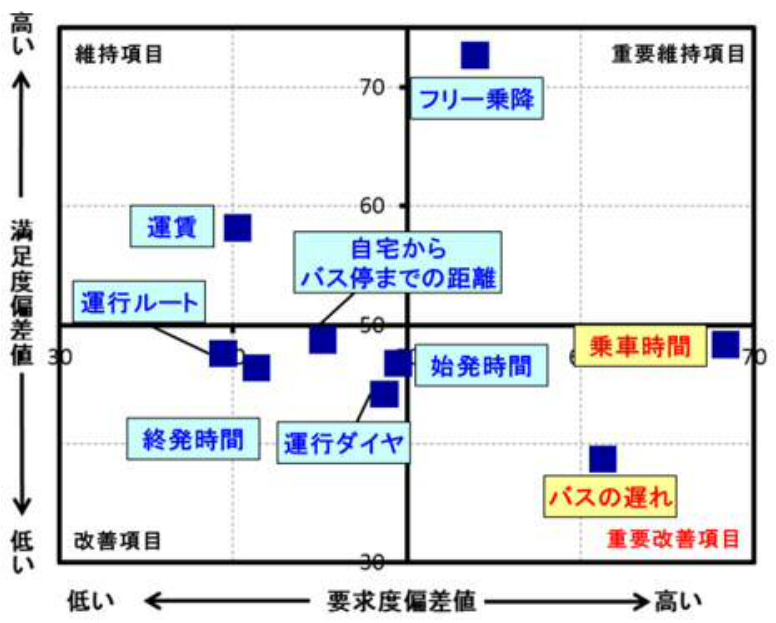

図-6 導入前における意識構造

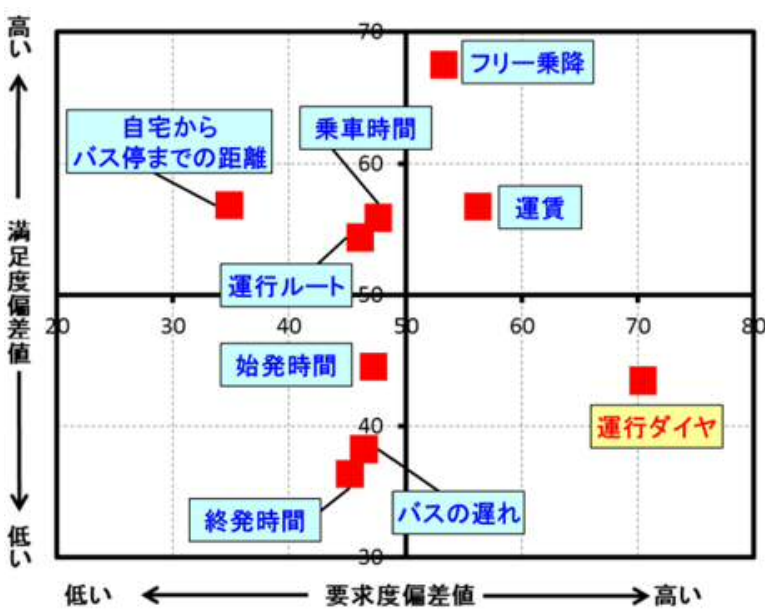

図-7 導入後における意識構造 
図-7 より, ディマンドバス利用者では, 重要改善項 目として「運行ダイヤ」が抽出され, 全項目の中で要求 度が最も高いことが分かる. また, ダイヤに関する項目 である「始発時間」と「終発時間」に着目寸ると, 両項 目ともに要求度は高くないが，始発時間と比較して終発 時間の満足度が低く, 満足度は最も低い結果となった。

これは「運行ダイヤ」の改善が利用者ニーズとして求め られており，特に「終発時間」について遅い便の設定が 求められていると考えられる。，一方で，満足度が相対的 に高い位置にプロットされた「自宅からバス停までの距 離」,「運行ルート」, 「フリー乗降」の3 項目につい ては，ディマンドバスが導入されたことによる広域的な ルート設定と，それに伴う自宅からバス停までの距離の 短縮及び，自由に乗り降りできる区間が従来と比較して 増えたことで満足度が相対的に高くなっているものと考 えられる.

\section{c）導入前後における意識構造の比較}

導入前後で得られた意識構造を比較したものを図-6 に示寸．なお，図-8 については導入前後で大きく変化

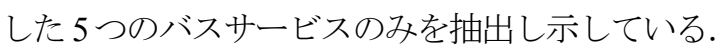

「自宅からバス停までの距離」と「運行ルート」に着 目すると，導入前後において改善項目から維持項目に位 置している.これは, ディマンドバスの導入による広域 的なルート設定が，自宅からバス停までの距離の短縮と 運行ルートの拡大につながったため, 利用者満足度が向 上し, 維持項目へと位置する結果になったものと考えら れる.

「バスの遅れ」，「乗車時間」の2 項目は導入前後で 要求度が低くなり,「乗車時間」については重要改善項 目から維持項目へと位置している.これは，ディマンド バス利用者の約 9 割が 60 歳以上の高齢者であることか ら，利用者意識としては乗車時間に対寸る抵抗はあまり 感じていないことが要因であると考えられる. また，平 成 26 年度の北見市地域公共交通会議資料では，「お客 同士が仲良くなり，楽しく利用している．」といった声 が挙げられていることから，バス自体が小型化されたこ とによって, 車内での地域住民同士の交流機会が増えた ため, 満足度が高くなり維持項目一位置したものと考え られる，一方，「バスの遅れ」は，相対的に要求度が低 くなっている.これは，利用者が事前予約をすることに よって, 利用者意識として必ずバスに乗れるという安心 感がうまれ, バスの遅れによる抵抗感が減少していると 考えられる，また「運行ダイヤ」に着目すると，重要 改善項目に位置していることから, 今後の継続的な運行 に向けて利用者ニーズに合った運行ダイヤへの改善が必 要であることが明らかとなった.

上記の結果を受けて，対象地区のバスダイヤを具体的 にどのように改善するべきかを検討する.

\section{6. アクセシビリティ指標の算出}

本研究では，対象地区住民の活動機会に着目し，既存 研究で用いられている活動機会の獲得水準を表すアクセ シビリティ指標 ${ }^{10)}$ を用いて, ディマンドバスの導入前後 でのバスダイヤについて，住民の活動機会がごの程度獲 得できているのかを定量的に示し，バスダイヤに関する 事前・事後評価を行う。さらに, 活動機会の獲得という 視点から新たなバスダイヤの設定を行い, 対象地区のバ スダイヤにおける具体的な改善策について検討する.

\section{(1) 対象地区のバスダイヤの概要}

旧路線バスのダイヤと現在のディマンドバスダイヤを を表-3に示す。

対象地区を出発する往路便を見ると, 従来と比較して, ディマンドバスのダイヤは午前中に多く便が設定されて おり，北見駅から地区一向から復路便では，終発便が従 来より遅い時間に設けられている. しかし，バスの運行 本数自体は 1 日 9 便となっており, 増便などのような抜 本的な改善を行ったとは言い難い.

\section{(2) 分析フロー}

本研究では，対象地区のバスダイヤを評価・検討する ため, 対象地区住民の日常的な外出における活動時間带 をアンケート調査によって把握した後, 図-9 のような 流れで分析を行う。

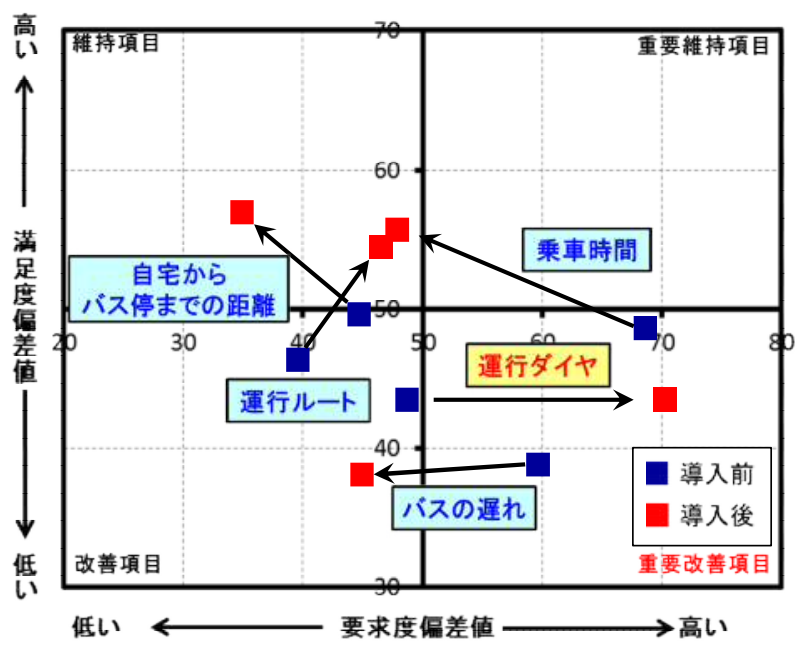

図-8 導入前後におけるバス利用者の意識構造の変化

表-3 導入前後でのバスダイヤ

\begin{tabular}{|l|c|c|c|c|c|}
\hline 往路便 & {$[1]$} & {$[2]$} & {$[4]$} & {$[6]$} & {$[8]$} \\
\hline \hline デイマンド゙スダイヤ & $7: 25$ & $8: 00$ & $10: 45$ & $13: 55$ & $16: 45$ \\
\hline 旧路線バスダイヤ & $7: 30$ & $9: 20$ & $13: 30$ & $16: 20$ & $18: 20$ \\
\hline 復路便 & & {$[3]$} & {$[5]$} & {$[7]$} & {$[9]$} \\
\hline デイマンドバスダイヤ & & $9: 45$ & $12: 40$ & $15: 00$ & $18: 30$ \\
\hline 旧路線バスダイヤ & & $9: 00$ & $12: 50$ & $16: 00$ & $17: 40$ \\
\hline
\end{tabular}


Case1) 事前・事後でのダイヤ評価 : 得られた地区住民 の活動時間帯を基に，活動機会の獲得水準をディマンド バス導入前後でそれぞれ算出し，比較することで，事 前・事後での活動機会獲得水準の向上を示す.

Case2) 活動機会獲得水準が最大となるダイヤ設定 : こ こでは，制約条件を考慮したバスダイヤの設定を行うた め, 現在運行しているディマンドバスの実際の便数を基 に，活動機会の獲得水準が最大となるバスダイヤの組み 合わせを算出する.

Case3) 増便した場合のダイヤ設定 : 増便したときに活 動機会の獲得水準がどのくらい変化するのかを示すため, 現状のディマンドバスダイヤから 1 便増便した場合のダ イヤ設定を行い，その時の獲得水準を算出する.

以上のような分析フローを通して，ディマンドバス導 入前後におけるバスダイヤの評価および，活動機会の獲 得水準が最大となるダイヤの算出を行い, 活動機会の獲 得という視点からどの便を組み替えた方が良いのか，ま た，増便した場合の獲得水準の向上がどのくらい見込め るのかを定量的に示し，今後のバスダイヤの具体的な改 善策を検討する．そこで，本分析では，活動機会の獲得 水準を表す指標としてアクセシビリティ指標を用いて分 析を行った。

\section{(3) アクセシビリティ指標}

\section{a) 地区のアクセシビリティ指標}

本研究で用いるアクセシビリティ指標 ${ }^{14)}$ は式(1)で表さ れる.これは，公共交通を利用して行う活動について， 移動と活動に利用可能な時間, 活動時間, 総移動時間, 公共交通の待ち時間を変数として, 実行可能な時間配分 の多様性を表す指標となっている. なお，ここでいう実 行可能な時間配分の多様性とは, 活動機会を獲得するこ とのできる時間の配分がどれだけ多くあるか(時刻を分 単位など離散的に捉えたとき，実行可能な活動の開始時 刻と終了時刻の組み合わせが何通りあるか)を意味して いる.

$$
A_{\max }=\sum_{i} \sum_{j} \frac{e^{-\beta\left(t_{j}-t_{i}\right)}}{\gamma}\left(1-e^{-\gamma\left(t_{j}-t_{i}-M\right)}\right) P_{i j}
$$

$$
\begin{aligned}
& t_{i} \quad \text { : 自宅を出発する時間帯 } \quad M \quad \text { : 総移動時間 } \\
& t_{j} \quad: \text { 自宅に帰宅する時間帯 } \quad \beta, \gamma \quad \text { : パラメータ } \\
& P_{i j}: \text { 時間帯 } t i, t j \text { に活動を行う人の比率 }
\end{aligned}
$$

式(1)を用いるにあたり，時間帯 $t_{i}$ に自宅を出発し時間 帯 $t_{j}$ に帰宅する活動は， $t_{i}$ の直前に出発するバスと, $t_{j}$ の 直後に帰宅するバスを利用して行うものとし，それ以外 のバスの利用は考えないものとする.すなわち外出パタ ーンを 1 通りと仮定している. 加えて，活動パターンが 2 つ上上場合は，活動パターンそれぞれについてのア
クセシビリティ值を算出し, 活動パターンの数だけ合算 すればよい.

また，式(1)は，地区住民が活動を行いたい時間帯に いつでも交通機関が利用可能である状態を想定しており, 活動時間帯がわかっているとき，それらの活動機会が全 て保障される場合のアクセシビリティ指標となっている.

\section{b) バスダイヤを考慮したアクセシビリティ指標}

次に，式(1)をもとに構築された，バスダイヤを考慮 したアクセシビリティ指標を式(2)に示す.

$$
A_{\max }=\sum_{i} \sum_{j} \frac{e^{-\beta\left(a_{l}-d_{k}\right)}}{\gamma}\left(1-e^{-\gamma\left(a_{l}-d_{k}-M\right)}\right) P_{i j}
$$

$$
\begin{array}{ll}
d_{k} & \text { : 地区の出発時刻 } \quad M \quad \text { : 総移動時間 } \\
a_{l} & : \text { 地区の到着時刻 } \quad \beta, \gamma \quad \text { : パラメータ } \\
P_{i j} & \text { : 時間帯 } t i, t j \text { に活動を行う人の比率 }
\end{array}
$$

上式では，ある地区を運行するバス路線が往路 1 日 $K$ 便，復路が $L$ 便で運行されているとしたとき，往路のバ スダイヤを $d_{k}(k=1, \cdots, K)$, 復路のバスダイヤを $a_{l}(l=1, \cdots$, $L)$ で表している。このとき, 自宅出発時間帯 $t_{i}$, 帰宅時 間帯 $t_{j}$ という活動について, $t_{i} \geqq d_{k}$ と $t_{j} \leqq a_{l}$ を満たすバス があれば活動機会を獲得できるとし，いずれか一方を満 たさないとき活動機会は獲得できないとする.すなおち, 式(1)における $t_{j}-t_{i}$ が $a_{l}-d_{k}$ に置き換えられる形となる. また，前提条件として，ここでは，ある都市の周辺部に 位置する地区を想定しており，その地区において，中心 部に行くことにより通勤, 通学, 買い物, 通院などの日 常生活に必要な活動機会が得られると仮定する.

\section{c) アクセシビリティを最大化するバスダイヤの設定}

地区住民の活動時間帯に対し，式(2)のアクセシビリ ティ值を最大化するバスダイヤの組み合わせを求める. 活動時間帯が与えられたとき, 式(2)はバスダイヤ $d_{k}$ と $a_{l}$ の関数となるため, アクセシビリティが最大となると きのバスダイヤの組み合わせは式(3)のように書ける.

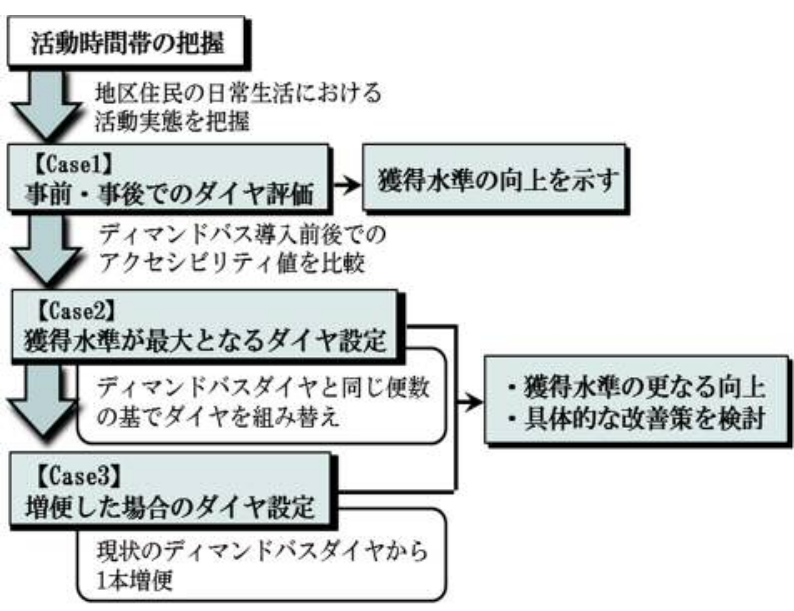

図-9 バスダイヤの評価・分析フロー 


$$
\begin{aligned}
& \left(d_{1}^{*} \ldots d_{K}^{*}, a_{1}^{*} \ldots a_{L}^{*}\right) \\
& =\arg \max \sum_{i} \sum_{j} \frac{e^{-\beta\left(a_{l}-d_{k}\right)}}{\gamma}\left(1-e^{-Z}\right) P_{i j}
\end{aligned}
$$

ただし, $\left(d_{1}^{*} \ldots d_{K}^{*}, a_{1}^{*} \ldots a_{L}^{*}\right)$ はアクセシビリティ值が 最大になるときのバスダイヤ出発時刻，到着時刻の組み 合わせであり, $Z=\gamma\left(a_{\Gamma}-d_{k}-M\right)$ である.

本研究では, 式(3)を用いて, 往路・復路のバスの便 数 $K$ 便と $L$ 便を所与とし, 現在運行している便数を基 にしたときのアクセシビリティが最大となるバスダイヤ の組み合わせを算出する。

なお，本分析は，同地区内のバス路線におけるアクセ シビリティ值の比較を目的としており，異なる地域特性 をもった地区間の比較を目的とした分析ではない．また， 既存研究 ${ }^{15}$ における対象地区 (兵庫県豊岡市) は, 人口 が約 9 万人 (北見市は約 10 万人) であり, 対象路線は, 従来運行されていた路線バスが見直され, 定員 10 人の ワゴン車を用いたコミュニティバスが 1 日 8 便で運行さ れている. これらの状況は, 本研究の対象地区と類似す る点が多い.

以上のことから，指標中のパラメータ值については既 存研究 ${ }^{15}$ の值を用いることとし $, \beta=0.188, \gamma=1.814$ とす る.また, 総移動時間は旧路線バスとディマンドバスの 実際の乗車時間として，それぞれ $M$ (旧路線バス $)=40$ 分, $M$ (ディマンドバス $)=50$ 分とする.

ここで，以上に示したアクセシビリティ指標を用いる にあたって, 対象地区住民の自宅出発時間帯 $t_{i}$ 及び帚宅 時間帯 $t_{j}$ を把握する必要がある。

\section{7. バスダイヤの評価と検討}

\section{（1）対象地区住民の活動実態の把握}

\section{a) アンケート調査概要}

本研究では対象地区住民の自宅出発時間帯 $\left(t_{i}\right)$ 及び帚宅 時間帯 $\left(t_{j}\right)$ を把握するため, 平成 26 年 11 月よりアンケー 卜調査を実施した。 調査の概要は表-4の通りである.

\section{b) 活動時間帯分布表の作成}

対象地区住民の日常生活の外出における活動時間带を, 表-5のような活動時間帯分布表として作成する.

この活動時間帯分布表は, 各時間帯の組み合わせに対 するその活動を行う頻度（1 日当たりの平均回数，例え ば週に 1 回なら 1/7) を人数分足し上げて集計し, 規準 化（100 分率表示）したものである. 一例として，午前 10 時頃に自宅を出発し, 午前 12 時頃に帰宅するという 活動を行う人の比率が 6.4(\%)であることを表している. この表を基にアクセシビリティ值が算出される.また, 自宅出発時間帯 $\left(t_{i}\right)$, 及び州宅時間帯 $\left(t_{j}\right)$ は一定の幅をもっ
た時間帯として設定され，本研究では 1 時間単位で時間 帯を区切ることとしている.

\section{(2) バスダイヤの事前・事後評価 (Case1)}

活動時間带分布表を基に，表-3に示した旧路線バスの ダイヤと現在のディマンドバスダイヤによって活動機会 がどのくらい獲得できるのかを定量的に示すため，式 (2)を用いてアクセシビリティ值を算出する，なお，旧 路線バスのときと現在において, 対象地区住民の活動時 間帯は同じものと仮定する. 分析結果として, ディマン ドバス導入前後におけるアクセシビリティ值の算出結果 を表-6に示す。

旧路線バスでは，アクセシビリティ值の合計が 1.298 であるのに対し, ディマンドバスは 2.646 となり，導入 前後で活動機会の獲得水準が向上していることが明らか となった．これは，旧路線バスのダイヤと比較して，デ イマンドバスのダイヤは，地区から北見駅一向かう往路 便が午前中に多く設定されているため, 往路便に対する 復路便の組み合わせが多くなり, 活動時間帯分布表の獲 得できる出発・帰宅時間帯の組み合わせが増えたためで あると考えられる。

表-4 アンケート調査概要

\begin{tabular}{|l|l|}
\hline 調查対象 & 15 歳以上の北見市川東地区住民·若松地区住民 \\
\hline 配布票数 & 川東: 726 票, 若松: 136 票 計: 862 票 \\
\hline 調査回収期間 & 平成26年11月20日 平成26年12月12日 \\
\hline 配布方法 & 川東地区:直接配布, 直接回収 若松地区: 郵送配布, 郵送回収 \\
\hline 回収票数 & 350 票 回収率: $41 \%$ \\
\hline 調査項目 & 個人属性, 外出目的, 外出時間帯, 外出頻度, 満足度(5段階評価)等 \\
\hline
\end{tabular}

表-5 地区の活動時間帯分布表

(百分率)

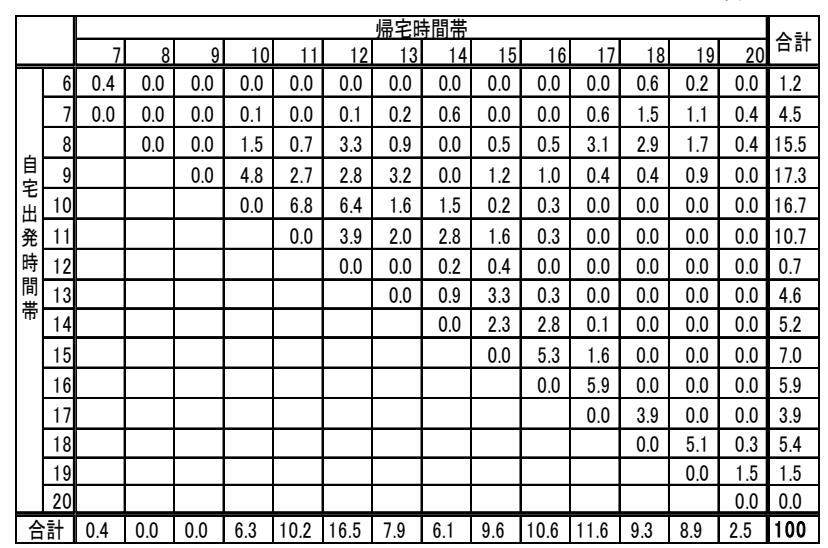

\begin{tabular}{|c|c|c|c|c|}
\hline 便名 & ディマンドバス & A值 & 旧路線バス & A值 \\
\hline [1] & $7: 25$ & 0.272 & $7: 30$ & 0.329 \\
\hline$[2]$ & $8: 50$ & 1.465 & $9: 20$ & 0.906 \\
\hline [4] & $10: 45$ & 0.693 & $13: 30$ & 0.063 \\
\hline$[6]$ & $13: 55$ & 0.217 & $16: 20$ & 0.000 \\
\hline$[8]$ & $16: 45$ & 0.000 & $18: 20$ & 0.000 \\
\hline 4 & 合計 & 2.646 & 合計 & 1.298 \\
\hline
\end{tabular}

表-6 アクセシビリティ值の算出結果 
ここで，現在のバスダイヤから，今後どのようなダイ ヤの再設定を行うべきかを検討するため，対象地区全体 の活動機会の獲得水準が最大となるバスダイヤの設定お よび，現在のディマンドバスダイヤから増便した場合の バスダイヤの設定を行った.

\section{(3) バスダイヤの設定と改善策の検討}

a) アクセシビリティが最大となるダイヤの設定 (Case2)

現在運行しているディマンドバスの運行本数と同じ便 数の基で, アクセシビリティ值が最大となるよう設定し た新たなバスダイヤと, ディマンドバスダイヤを比較し たものを表-7 に示す．表-7では，新たバスダイヤにお けるアクセシビリティ値は 5.248 となり, 現在のダイヤ と比較してアクセシビリティ值が大きく向上している.

新たなダイヤでは, 往路便の第[2]便が 10 時頃となっ ており, 復路便の第[3]便は 11 時頃となっている. また, 第[7], [9]便では, 16 時，17 時頃と夕方に集中している ことがわかる.これらのことから，対象地区住民が 10 時頃に自宅を出発し, 11 時頃に帰宅寸る活動と, 15 時, 16 時頃に出発し, 夕方に帰宅する活動が比較的多く, 設定されたバスダイヤは，それらの活動をうまく獲得で きているため, 同じ便数であってもダイヤの組み方によ って, アクセシビリティ値に大きな差が生じたものと考 えられる.

これらの結果より, 今後, バスダイヤの組み方によっ て対象地区全体の活動機会の獲得水準は更に向上寸る可 能性があることを示した。

b) 増便した場合のダイヤ設定 (Case3)

現在運行しているディマンドバスダイヤから 1 便増し た場合のダイヤ設定を行った。ここで，増便する際の時 間帯の選択条件としては，式(2)に示したバスダイヤを 考慮したアクセシビリティ算出式において，アクセシビ リティ值が最も向上する時間帯を選択し，1 便増便させ る方法を取った. 復路便の[5]便を 12:00 に設定した.こ こでは, ディマンドバスダイヤから 1 便増便した場合の ダイヤと, 表-7 に示したバスダイヤを組み替えた場合 のダイヤを比較し，今後の対象地区のバスダイヤについ てダイヤを組み替えるべきか，または，増便するべきか を検討した．増便した場合のバスダイヤの設定結果とダ イヤを組み替えた場合の新たなバスダイヤを比較したも のを表-8に示す.

増便した場合のバスダイヤでは, アクセシビリティ值 が 3.617 であるのに対し，ディマンドバスと同じ便数の 基で, バスダイヤを組み替えた場合のダイヤでは, 5.248 であり, 結果として増便するよりも, 現在のディ マンドバスダイヤと同じ便数の基でバスダイヤを組み替 えた方が，アクセシビリティ值としては高い值を示すこ とが明らかとなった．このことから，対象地区全体のア
クセシビリティの向上という視点に基づいたとき, 現状 のダイヤから増便するよりも，まず同じ便数の基でバス ダイヤを組み替えることで対象地区の活動機会の獲得水 準は大きく向上寸る可能性があると考えられる.

\section{(4) 分析結果のまとめ}

バスダイヤの評価・分析の結果を図-10に示す. 事 前・事後評価では，ディマンドバス導入前後で，地区の 活動機会の獲得水準が向上していることが明らかとなっ た.さらに，今後の改善策として，現在運行しているデ イマンドバスダイヤから増便するよりも，まず現状の便 数の基で, 地区住民の活動を行う比率が高い午前中と夕 方の運行密度を高くするようなバスダイヤに組み替える, 寸なわち，ダイヤ自体の体質改善を行うことによって， 地区全体の活動機会の獲得水準は更に向上寸る可能性が あることが明らかとなった。 なお，以上に示した結果は 地区住民の活動機会にのみ着目した結果であり，バスダ イヤの実現可能性を検討するためには, 車両台数や運行 効率等の制約を十分に考慮する必要があると考えられる.

表-7 設定したバスダイヤと現状のバスダイヤの比較

\begin{tabular}{|l|c|c|c|c|c|}
\hline 往路便 & {$[1]$} & {$[2]$} & {$[4]$} & {$[6]$} & {$[8]$} \\
\hline \hline デイマンドバスダイヤ & $7: 25$ & $8: 50$ & $10: 45$ & $13: 55$ & $16: 45$ \\
\hline 新たなバスダイヤ & $8: 00$ & $10: 00$ & $11: 00$ & $15: 00$ & $16: 00$ \\
\hline 復路便 & & {$[3]$} & {$[5]$} & {$[7]$} & {$[9]$} \\
\hline デイマンドバスダイヤ & & $9: 45$ & $12: 00$ & $12: 40$ & $15: 00$ \\
\hline 新たなバスダイヤ & & $11: 00$ & $12: 00$ & $16: 00$ & $17: 00$ \\
\hline デイマンドバスダイヤのA值 & & 2.646 & & \\
\hline 新たなバスダイヤのA值 & 5.248 & \\
\hline
\end{tabular}

表-8 増便した場合とダイヤを組み替えた場合の比較

\begin{tabular}{|l|c|c|c|c|c|}
\hline 往路便 & {$[1]$} & {$[2]$} & {$[4]$} & {$[6]$} & {$[8]$} \\
\hline \hline 1便増便した場合のダイヤ & $7: 25$ & $8: 50$ & $10: 45$ & $13: 55$ & $16: 45$ \\
\hline 新たなバスダイヤ & $8: 00$ & $10: 00$ & $11: 00$ & $15: 00$ & $16: 00$ \\
\hline 復路便 & {$[3]$} & {$[5]$} & {$[7]$} & {$[9]$} & {$[10]$} \\
\hline 1便増便した場合のダイヤ & $9: 45$ & $12: 00$ & $12: 40$ & $15: 00$ & $18: 30$ \\
\hline 新たなバスダイヤ & $11: 00$ & $12: 00$ & $16: 00$ & $17: 00$ & \\
\hline 1便増便した場合のダイヤのA值 & 3.617 \\
\hline 新たなバスダイヤのA值 & 5.248 \\
\hline
\end{tabular}

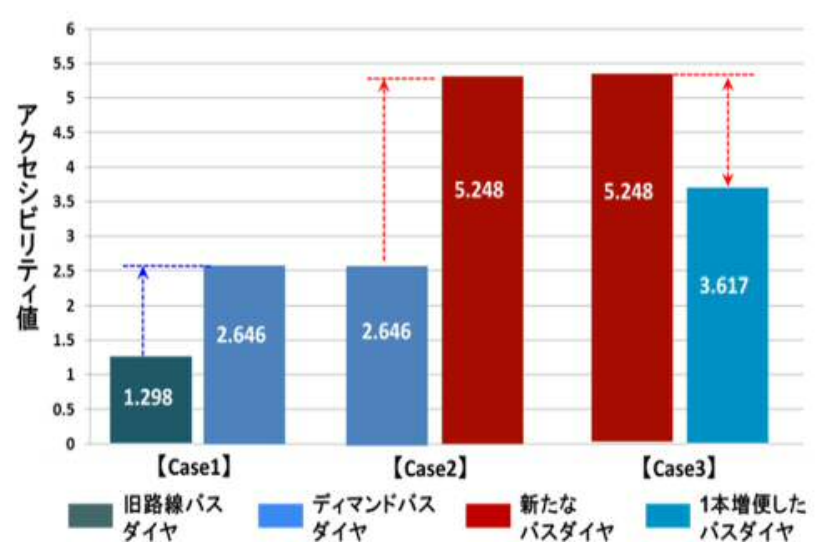

図-10＼cjkstart各バスダイヤのアクセシビリティ值の比較 


\section{8. おわりに}

本研究では，意識構造分析により明らかとなった「運 行ダイヤ」の改善の必要性を受け，地区住民の活動機会 に着目し，アクセシビリティ指標を用いてバスダイヤの 事前・事後評価及び，具体的な改善策の検討を行った. 本研究で示した分析結果は, 地区住民の活動機会のみに 着目して得られた解であり, 運行効率やコスト等の制約 を考慮した最適解ではない. しかし, 現状としてバスダ イヤ設定の際は，一般的に事業者に委ねられることが多 く，“かん”や“経験”に寄るところも多い，そのため， 住民懇談会などの場において，本分析結果を提示するこ とにより，その結果を受けて自治体や事業者，住民らが 調整したり，代替案を適格に選択寸ることが可能になる など，バスダイヤ設定の際の対象地区住民一の合意形成 ツールとしての役割を担うものであると考える.

また，実際のフィールドにおける運行計画では，運行 費用などのコストによる制約を必ず考慮しなければなら ない，そのため今後の課題としては，対象地区住民の活 動機会を獲得可能なバスダイヤを実現するため, 運行コ ストを考慮した分析が必要である，具体的には，ダイヤ を改善することによるアクセシビリティ值の増分に対す る運行コストの試算といった, 活動機会とコストの両視 点を考慮したバスダイヤの評価および検討が挙げられる。

謝辞 : 本研究にあたり, 北見市, 北見市地域公共交通 会議の担当者に協力をいただいた。ここに謝意を表す。

\section{参考文献}

1) 北見市: 北見市地域公共交通計画

2）北見市ホームページ: http://www.city.kitami.lg.jp

3) 坂本邦宏, 谷島賢, 栗田唐: 路線バス再編の効果と 住民意識変化一ときがわ町地域公共交通総合連携計
画一, 土木計画学研究・講演集, Vol. 44, p. 35, 2011.

4) 小林昂弘, 岡村敏之, 中村文彦: バス到着時刻情報 の取得実態と利用者の意識に関する研究, 土木計画 学研究・講演集, Vol. 44, p. 57, 2011.

5）塚田伸也, 湯沢昭, 森田哲夫 : 公共交通不便地域に おけるバス再編・新駅設置に関する忩識分析一群馬 県吉岡町を対象に一, 土木計画学研究・講演集, Vol. 48, p. 151, 2013.

6) 斎藤奈穂, 高野伸栄：需要減少を踏まえたバス事業 者の意識構造分析, 土木計画学研究・講演集, Vol. 48, p. 247, 2013.

7) 金井昌信, 青島縮次郎, 杉木直 : バス非利用者のバ ス路線に対する認知度を考慮した今後のバス利用意 向とバス路線存続意向との関連分析, 土木計画学研 究・講演集, Vol. 45, p. 35, 2002.

8) 岸邦弘, 佐藤岸邦宏, 佐藤馨一: 住民ニーズに基づ いた過疎地域における生活交通手段の策定プロセス, 土木計画学研究・論文集, Vol. 23, No.3, pp. 591-597, 2006.

9）森山昌幸，藤原章正，杉恵頼寧：GIS を活用した中山 間地域の公共交通計画支援ツールの開発，土木計画 学研究・論文集, Vol. 21, No. 3, pp. 759-768, 2004.

10) 岸野啓一, 喜多秀行, 寺住奈穂子 : 活動機会の獲得 水準最大化を目指したバスダイヤの設定法, 土木計 画学研究・論文集, Vol. 27, No. 4, pp. 633-641, 2010.

11）北見市：北見市地域公共交通会議資料，2013.4.

12) 南学: 学生による授業への CS 分析の適用, 三重大学 教育学部付属教育実践センター紀要, No. 27, pp. 2934, 2007.

13）大西智司：農家満足度調査を活用した農業技術評価 - CS ポートフォリオ分析の適用, 香川県農業試験場 研究報告, No. 51, pp. 61-66, 1999.

14）岸野啓一: 活動機会の獲得水準に着目した過疎地域 の公共交通計画に関する方法論的研究, 博士(工学)論 文, 2012 .

15) 谷本圭志, 牧修平, 喜多秀行: 地方部における公共 交通計画のためのアクセシビリティ指標の開発, 土 木学会論文集 D, Vol. 65, No. 4, pp. 544-553, 2009.

(2015. 2. 27 受付)

\section{STUDY ON IMPROVEMENT PLANS AND EXTRACTION OF THE BUS SERVICE REFINEMENT BASED ON THE CHANGE OF USERS CONSCIOUSNESS STRUCTURE}

\section{Tomohide SASAKI, Kiyoshi TAKAHASHI, Taku SHIBAZAKI and Genki OOI}

The proof service of the Demand Bus was implemented for the purpose of the cancellation of the public transport blank and bus transit convenience improvement form December, 2012 in Kawahigashi district and Wakamatsu district that are located in Kitami city, Hokkaido. And full-scale service is implemented now. This Study elucidated users consciousness structure before and after introduction of Demand bus by CS portfolio analytical method. As a result improvement of the satisfaction for the bus service and changes of users consciousness structure was elucidated. Furthermore, refinement for continuous service was extracted and specific improvement plans was examined. 